\title{
Development Dilemma and Path Choice of University Students on Entrepreneurship Education
}

\author{
Sanbao Liu \\ Huazhong Agricultural University, Wuhan Hubei, 430070, China
}

Key words: University students, Entrepreneurship education, Dilemma, Path.

\begin{abstract}
To launch entrepreneurship education among university students is to satisfy the crying needs of economic and social development and higher-education comprehensive reform. This article analyses the development dilemma encountered by entrepreneurship education in the four following aspects: society's understanding deviation of entrepreneurship education essence, students' single-faceted opinion about entrepreneurship, school's absence of assistance and omission of the commercialization of research findings. This paper puts forward the work ideas of entrepreneurship education - two concepts and five collaborations to hold on.
\end{abstract}

\section{Introduction}

To strengthen the entrepreneurship education of university students, not only can meet the demands of economy and society, but also help education actively fit the development of economy and society as an important reform measure. In order to fully implement the national development strategies of "Rejuvenating the Country through Science and Education" and "Build an Innovative Country", especially to solve problems arise from national core competitiveness, economic structure transformation and university student employment in the context of new normal, since the 18th CPC National Congress, the Central Committee and the State Council see "the mass entrepreneurship and multitude innovation" as key ways to enhance the wellbeing of the public and the development of the country. From this perspective, the government has established a set of policies, mainly in public services, venture capital support, mentors' assistance, hatch sites and reduction or exemption of tax, attempting to help college students start up their careers.

\section{Development Dilemma of University Students on Entrepreneurship Education}

Research shows that one-man entrepreneurship could offer jobs for five individuals. In 2016, college students in the whole country soared up to 7.56 million, hitting a new high in history. The employment pressure of college students grows year by year, and also the structural contradictions are becoming more obvious. Therefore, we should cultivate the new engine by mass entrepreneurship and multitude innovation, combine entrepreneurship and employment and then expand employment by encouraging business startups. In this way, we could promote people's wellbeing, economic restructuring and social harmony as well as stability. However, the current entrepreneurship education stills lag behind in concepts, ambience, faculty, investment and conditions.

\section{Society's comprehending deviation of Entrepreneurship Education}

At present, with strong support and advocacy of the Party and government, an increasing number of students begin to launch start-ups in campus. While the society holds circumscribed opinions towards the positioning of entrepreneurship. Some people regard this kind of education only as a practice in college life; some people claim that this education encourages students to establish companies for 
more money; while some others believe that it is simply for the purpose of stress alleviation. We can see that some comments contain prejudice, ignore pioneering and risk-taking spirits, independent consciousness and entrepreneurial ability_— the very natures of entrepreneurship education.

\section{Students' Single-faceted Opinion about Entrepreneurship}

When it comes to college students' start-ups, there are three states to describe them, namely: aimlessness, busyness and daze. "Aimlessness" means that some students are not that into entrepreneurship, instead, they are just following suit of people who have established companies; "busyness" shows that students who genially devoted time and energy to business would encounter triple pressure of school, entrepreneurship and family; and "daze" points that more students preliminarily establish business for more allowance. Therefore they are absent of projects with commercial prospects. Many of their ideas cannot survive the market.

\section{School's Absence of Assistance}

The majority of entrepreneurship classes takes the form of optional course, which means that the teaching force is relatively weak as many teachers have no solid foundation or training in this area and they also have many other tasks to do. Also the absence of localization textbooks combined with professional features lead to tedious content, tepid students and unconfident teachers. Apart from the courses, an improved support system of entrepreneurship education is critical for entrepreneurial students. But the capital, platform, policies and outside resources the school could offer are really limited.

\section{Omission of the Commercialization of Research Findings}

Some scientific and technological workers scorn at companies and market operation in that they have little understanding of market due to long distance. However, many universities regard off-post entrepreneurship of scientific research personnel as " freeloading " or " establishment without performance of duty ", so the faculty are not willing to, more specifically, afraid to off-the-job. In this regard, the research findings of colleges are often unable to transform into achievements at "the last mile", so there are few researchers taking advantage of findings to start new business. The related data displayed that only $2.5 \%$ of the researchers devoted to entrepreneurship, while scientific research institutions constituted only for 1.2\%. This implies that, in the full swing of entrepreneurial activities, the grassroots entrepreneurs are the real active groups, while scientific and technical personnel from universities and scientific institutions are missing for a large proportion.

\section{Path Choice of University Students on Entrepreneurship Education}

Undergraduate entrepreneurship education is a series of practice activities, possessed with concept, system, structure and logic. Therefore, our work shouldn't limit to certain questions, instead, the educators and managers should be bold to break limits and reform current education management system and mechanism.

\section{Firm Establishment of Two Concepts}

\section{Entrepreneurship Education aims at the All-round Development of People}

Entrepreneurship education cannot flourish everywhere. It should be in conformity with the talent cultivation guidelines in school and demands of students' growth. Human's all-round development mainly rest in several fields, namely, spirit, morality, personality, intelligence, ability and realm. While what the entrepreneurship education favors is the training of personality and comprehensive quality, and what it stresses is the motivation of consciousness, initiative and creativity. In this perspective, entrepreneurship is the epitome of liberal education, and the ultimate goal would be the integrated development of human beings. Specifically, the abilities to survive and stand out from the crowd should be fostered for a solid foundation in the future, for being a leader or a mainstay in some professions and trades. 
Entrepreneurship Education Should Encourage Innovation, Tolerance and Failure

Materialistic Dialectics has taught us that every coin has two sides. Entrepreneurship is the highest level of employment, while also comes with the highest risk. In the academicians of the Chinese Academy of Sciences and Chinese Academy of Engineering held in 2014, CPC Secretary General Xi Jinping highlighted:"Success is valued, failure is more needed to be tolerated, and the baton function of talent evaluation is required to be completed."For entrepreneurship, failure toleration equals to innovation encouragement and continuous creation. Only in this way can we truly grasp the basic rules of inner logic and talent growth of graduate entrepreneurship. Just as "Silicon Valley Spirit" demonstrates: "Failure is the most important product of our own", "Failure toleration is more important than success creation."

\section{Stick to the five collaborations}

Adhere to the collaboration between the classroom teaching and extracurricular teaching

Entrepreneurship education is composed of theories and practice. So we need to break the ice between the classroom teaching and extracurricular teaching, transforming from singular form education into the collaborative mode. On one hand, the entrepreneurship education system should be centered by curriculum, in detail, widen this education into the talent training program. The entrepreneurship courses facing all students should focus on various areas of teaching, mainly curriculum choice, teaching methods arrangement, process design, outcomes evaluation, faculty training and teaching management system, solving the teaching problems arise from the entrepreneurship courses fundamentally. On the other hand, entrepreneurial education should be more involved in the extracurricular teaching. More specifically, integrate the extracurricular teaching training program and actively launch activities related to entrepreneurship like lectures, competitions, camp, pioneers selection, docking fair between projects and capital, forming a entrepreneurship system with mutual independence and interinfiltration.

Adhere to the collaboration between entrepreneurship education and professional education

Nowadays, the career-creation education becomes uniformity. However, universities should stand on the features and advantages on their own, then strengthen the fusion between entrepreneurial and professional education, with the attention being paid to the innovative and potential high-level talents. At great length, firstly, based on the original excellent scientific research projects and achievements, colleges should invite experts and scholars to offer scientific research cases with their own experiences, by this means to enlighten the students with scientific research thinking and also incubate the cultivable scientific research projects into entrepreneurship ones. Secondly, collect the entrepreneurial experiences of outstanding alumni and invite some entrepreneurs to open classes talking about start-up cases. In these classes, the alumni would teach students to discover and grasp opportunities, face and figure out problems, with a view to inspiring them, bringing new thoughts and hoisting abilities of the students. Thirdly, in terms of practical teaching reform, universities should combine several fields like major arrangement, practical teaching, self-employment practice and industrial demands, and then explore diversified school-enterprise cooperation modes, like "Entrepreneurship Class" and "Future Entrepreneurs Camp", for the purpose of satisfying the needs of innovative and entrepreneurial talents cultivation.

Adhere to teacher-directed and student-centered collaboration

Entrepreneurship education is highly practical and interactive, and requires close cooperation between teachers and students. To start with, the first would be the diversified faculty. A batch of sophisticated entrepreneurship teachers, tutors and business venture mentors, specialized in teaching, instructing, marketing should be cultured. For example, to start with, universities could add some pilot non-institution establishment teachers with entrepreneurial practice, and employ some entrepreneur alumni and investment managers to design and teach classes all along. These efforts are taken to get through the boundaries between industry and school and truly enhance teachers' coaching skills. Furthermore, bring more technology achievements into entrepreneurship. Schools, according to the national policies, should introduce Implementing Measures for the Management and 
Promotion of Scientific and Technological Achievements Transformation, and for the teachers who have contributed measurably in this area should be in preferable position in post-setting, job appointment, expert-application and treatment distribution. Last but not least, the subject role of students should be highlighted. Students are not enthusiastic about the entrepreneurship, for that matter, colleges should intensify the reform in education and firmly establish the concept - students are the heart. For instance, further improve the instructions in the flexible educational system; draw up new ways to count innovative and entrepreneurial credits and clearly define the scope of these two aspects; reform the traditional talent evaluation mode, and in the specific quality evaluation, the innovative and entrepreneurial talents should be assessed on the relevant abilities, reducing the formalities carried from the academic talents training.

Adhere to the collaboration of resources from both inside and outside of school

Entrepreneurship education boasts openness and integration. It's hard to develop on one's own. Universities collect talent and scholars, while for entrepreneurs, maybe no resources. To vigorously promote entrepreneurship education, we must consider the actual situations of universities, and then allocate social resources, improve docking mechanism, build collaborative platform, diligently facilitate cooperation among schools, enterprises and locals, attract social resources to invest into innovation and entrepreneurial talent training. By means of the market, we could set up convenient and open practice bases or space equipped with, innovation and entrepreneur, online and offline, incubation and investment, maximally removing the blocks in innovative development and students' entrepreneurship.

Adhere to the collaboration between atmosphere building and full-support offering

Surrounded by an innovation-encouraging and failure-tolerating campus atmosphere, a large quantity of entrepreneurial talents would spring up. Therefore, colleges must focus on building the entrepreneurial atmosphere, absorb entrepreneurship education into the teaching, student work, faculty assessment system, reinforce the cultivation of entrepreneurial model and create an entrepreneurial culture. In addition, the initial stage of entrepreneurship is the most difficult and dangerous period for college students. Given this situation, colleges should offer full support. For example, provide classified guidance services for students who participate in innovative and entrepreneurial training and practice, mainly, project demonstration and business plan declaration; for students who are in the middle of start-ups, universities should regularly launch lectures in tax benefits, declarations and training; give key support to certain layers and kinds of highly innovative and promising entrepreneurial projects, in order to give the students a leg up to get them going.

\section{Acknowledgement}

Humanities and Social Sciences Project"Students' Entrepreneurial Education and Practical Research from Agricultural Universities" aided by special funds in HAZU(Project Number: 2015RW0016)

\section{References}

[1] State Council. Opinions on Employment and Entrepreneurship under New Situation , 2015-4-27.

[2] Qiu Chenhui. Why Lack Scientific Researchers-Main Force of Innovation and Entrepreneurship, China Youth Daily, 2016-1-19.

[3] Zhang Xiongwu. Establishment of Diversified and Collaborated Cultivation Mechanism of Innovative and Entrepreneurial Talent in Universities, Journal of National Institute of Education Administration, 2016(4).

[4] Huang Zhaoxin, Wang Zhiqiang. On Integration of Entrepreneurial and Professional Education in Colleges and Universities, Education Research, 2013(12). 